\title{
THE ORTHOGONAL PROJECTIONS AND SEVERAL INEQUALITIES
}

\author{
Nicuşor Minculete And Marek NiezgodA*
}

Abstract. In this article we study several inequalities related to the orthogonal projections and we established new results related to a pre-Hilbert space. Among these results we will mention the inequality of Ostrowski. We present an improvement of the inequality between the numerical radius of an operator and the norm of an operator and we also show other inequalities for a bounded linear operator. Finally, we show Grüss type inequalities on double ice-cream cones.

Mathematics subject classification (2010): 46C05, 26D10, 26D15.

Keywords and phrases: Pre-Hilbert space, Cauchy-Schwarz inequality, Ostrowski inequality, Grüss type inequality.

\section{REFERENCES}

[1] Y. J. Cho, M. Matić And J. PeČARIĆ, On Gram's determinant in 2-inner product spaces, J. Korean Math. Soc., 38, 6 (2001), 1125-1156.

[2] J. A. Clarkson, Uniformly convex spaces, Trans. Amer. Math. Soc., 40, (1936), 396-414.

[3] S. S. DRAGOMIR AND J. SÁndor, Some inequalities in pre-Hilbertian spaces, Studia Univ. BabesBolyai Math., 32, 1 (1987), 71-78.

[4] S. S. DRAGOMIR, Improving Schwarz Inequality in Inner Product Spaces, Linear and Multilinear Algebra, 67, 2 (2019), 337-347.

[5] S. S. DRAGOMIR, On Bessel and Grüss inequalities for orthonormal families in inner product spaces, Bulletin of the Australian Mathematical Society, 69, 2 (2004), 327-340.

[6] S. S. DRAGOMIR, A potpourri of Schwarz related inequalities in inner product spaces (II), J. Inequal. Pure Appl. Math., 7, 1 (2006), Article 14.

[7] S. S. DRAGOMIR, A generalization of Grüss's inequality in inner product spaces and applications, J. Math. Anal. Appl., 237, (1999), 74-82.

[8] S. S. DRAGOMIR, A Grüss type discrete inequality in inner product spaces and applications, J. Math. Anal. Appl., 250, (2000), 494-511.

[9] S. S. DRAGOMIR, Some Grüss type inequalities in inner product spaces, J. Inequal. Pure Appl. Math., 4, 2 (2003), Article 42.

[10] S. S. DRAGOMIR, Some companions of the Grüss inequality in inner product spaces, J. Inequal. Pure Appl. Math., 4, 5 (2003), Article 87.

[11] G. GRÜSs, Über das maximum des absoluten betrages von $\frac{1}{b-a} \int_{a}^{b} f(x) g(x) d x-$ $\frac{1}{(b-a)^{2}} \int_{a}^{b} f(x) d x \int_{a}^{b} g(x) d x$, Math. Z., 39, (1934), 215-226.

[12] K. E. Gustafson And D. K. M. Rao, Numerical Range. The Field of Values of Linear Operators and Matrices, Springer-Verlag, New-York, 1997.

[13] C. LUPU AND D. SCHWARZ, Another look at some new Cauchy-Schwarz type inner product inequalities, Appl. Math. Comput., 231, (2014), 463-477.

[14] L. Maligranda, Some remarks on the triangle inequality for norms, Banach J. Math. Anal., 2, (2008), 31-41.

[15] N. Minculete, Considerations about the several inequalities in an inner product space, J. Math. Ineq., 12, 1 (2018), 155-161.

[16] N. Minculete, Some Refinements of Ostrowski's Inequality and an Extension to a 2-Inner Product Space, Symmetry, 11, (5), (2019), 707, doi:10.3390/sym11050707. 
[17] D. S. Mitrinović, J. PeČAriĆ And A. M. Fink, Classical and New Inequalities in Analysis, 740 pages, Kluwer Academic, Dordrecht, 1992.

[18] C. P. Niculescu And L. E. Persson, Convex Functions and Their Applications: A Contemporary Approach, Second Edition, 256 pages, Springer, 2018.

[19] M. NiezGodA, On the Chebyshev functional, Math. Ineq Appl., 10, 3 (2007), 535-546.

[20] M. NieZGodA, Translation-invariant maps and applications, J. Math. Anal. Appl., 354, (2009) 111124.

[21] M. NiEZGODA, A new inequality of Ostrowski-Grüss type and applications to some numerical quadrature rules, Comput. Math. Appl., 58, (2009), 589-596.

[22] M. NiezGodA, Grüss and Ostrowski type inequalities, Appl. Math. Comput., 217, (2011), 97799789.

[23] I. PERIĆ AND R. RAJIĆ, Grüss inequality for completely bounded maps, Linear Algebra Appl., 390, (2004), 287-292.

[24] P. F. ReNAUd, A matrix formulation of Grüss inequality, Linear Algebra Appl., 335, (2001), 95-100.

[25] S. V. SundeR, Operators on Hilbert Space, Springer, 2016.

[26] N. Ujević, A new generalization of Grüss inequality in inner product spaces, J. Math. Anal. Appl., 250, (2000), 494-511. 